\title{
A FACILE SYNTHESIS OF 2-(4-(BENZO[D]THIAZOL-2-YL) PHENYLIMINO) THIAZOLIDIN-4-ONE AND 2-(4-(BENZO[D]THIAZOL-2-YL) PHENYLIMINO)-5- ARYLIDENETHIAZOLIDIN-4-ONES
}

\author{
P. Uma, K. C. Rajanna*, Y. Hemanth Sriram and P. K. Saiprakash \\ Department of Chemistry, Osmania University, Hyderabad-500 007, T.S. (India) \\ *E-mail: kcrajannaou@yahoo.com
}

\begin{abstract}
Facile synthesis of 2-(4-(benzo[d]thiazol-2-yl) phenylimino) thiazolidin-4-one and 2-(4-(benzo[d]thiazol-2-yl) phenylimino)-5-arylidenethiazolidin-4-ones has been accomplished in this study. 4-(benzo[d]thiazol-2-yl)benzenamine (1) reacts with ammonium thiocyanate in presence of Hydrochloric acid to give 1-(4-(benzo[d]thiazol-2yl)phenyl)thiourea (2) which on reaction with Chloroacetylchloride offer 2-(4-(benzo[d]thiazol-2yl)phenylimino)thiazolidin-4-one (3). Compound 3 condensed with different aldehydes to produce 2-(4(benzo[d]thiazol-2-yl) phenylimino)-5-arylidenethiazolidin-4-ones (4a-j). Minimal inhibitory concentration (MIC) measurement and "in vitro" antimicrobial assay (biological activity) of the prepared compounds were also studied against different types of bacteria viz., Staphylococcus aureus (Sp1), Klebsiella pneumoniae(Sp.2), Proteusmirablis (Sp3), and fungi such as, Fusarium Chlamydosporium(Sp4.), Macrophominaphaseolina (Sp5), using tetracycline and nystatin standards. The studies revealed that the prepared compounds exhibit fairly good antimicrobial activity.

Keywords: Facile synthesis; 2-(4-(benzo[d]thiazol-2-yl) phenylimino) thiazolidin-4-one; 2-(4-(benzo[d]thiazol-2yl) phenylimino)-5-arylidenethiazolidin-4-ones; antimicrobial (biological) activity.
\end{abstract}

(c) RASĀYAN. All rights reserved

\section{INTRODUCTION}

Heterocyclic compounds bearing thiazolidine moiety have received the attention of chemists and biologists owing to their wide range of promising biological activities. Some thiazolidine derivatives have better activity than standard drugs and could become a new drug for the market in future ${ }^{1-6}$. Moreover, the thiazole nucleus is an essential part of some penicillin varities, which have revolutionized the treatment of infectious diseases ${ }^{6}$. Kanchan Taori's research group ${ }^{7}$ isolated Largazole (A novel cytotoxic cyclodepsipeptide) from the marine cyanobacterium Symploca sp. collected in the Florida Keys. It possesses densely assembled unusual structural features, containing a rare 4-methylthiazoline linearly fused to a thiazole in its cyclic core and an undescribed 3-hydroxy-7-mercaptohept-4-enoic acid unit incorporated in an ester, thioester, and amide framework. It exhibited potent antiproliferative activity and preferentially targets cancer cells over nontransformed cells. This research group also stated that the antimicrobial activity of thiazole derivatives arises due to the presence of a $(\mathrm{S}-\mathrm{C}=\mathrm{N})$ toxophoric unit present in the thiazole ring system. This unit enhances lipid solubility with hydrophilicity, is easily metabolized by routine biochemical reactions, and is noncarcinogenic in nature ${ }^{7}$. Kumar and co-workers ${ }^{8}$ synthesized a group of 3[4'(pchlorophenyl) thiazol-2'-yl]-2-[(substituted azetidinone/thiazolidinone)-aminomethy]-6bromoquinazolin-4-ones and screened them for anti-inflammatory and analgesic activities. In addition, benzothiazole derivatives with an extended conjugated system are also known to exhibit longer fluorescence lifetimes. ${ }^{9}$ Literature survey showed that 4-thiazolidinones are associated with a wide range of biological properties ${ }^{10-13}$. On the other hand thiazolidinedione derivatives are pharmaceutically important scaffolds and potential chemotherapeutic agents for medicinal chemistry. ${ }^{14-21}$ Therefore, it will be important to use 2, 4-thiazolidinediones as aldol nucleophilic donors ${ }^{18,19}$ for the preparation of new and functionalized derivatives. Various imidazopyridines are reported as potential antibacterial, antimalarial and 
diuretic agents. In view of the biological activities, it is considered worthwhile to synthesize compounds having both moieties. In the present study, the authors have developed facile synthesis of 2-(4(benzo[d]thiazol-2-yl)phenylimino) thiazolidin-4-one and 2-(4-(benzo[d]thiazol-2-yl) phenylimino)-5arylidenethiazolidin-4-ones (4a-j) and efforts were made to explore their biological activity studies.

\section{General}

\section{EXPERIMENTAL}

Chemicals used were procured from SD (Fine Chemicals, India), Aldrich (India), or Emerck. Reagent quality solvents were obtained from Avra chemicals (India), and distilled prior to use. Varian $400 \mathrm{MHz}$ instrument to obtain ${ }^{1} \mathrm{H}$ NMR spectra with TMS as internal standard and chemical shifts are expressed $\delta$ ppm. DMSO- $\mathrm{d}_{6}$ was used as solvent. Mass spectra were recorded on a Hewlett Packard mass spectrometer operating at 70ev. Precoated silica gel TLC plates (60F-254) obtained from E- Merck were used for monitoring progress of the reaction. Iodine was used as a developing agent. IR spectra were recorded on potassium bromide disks on a Perkin-Elmer 383 spectrophotometer.

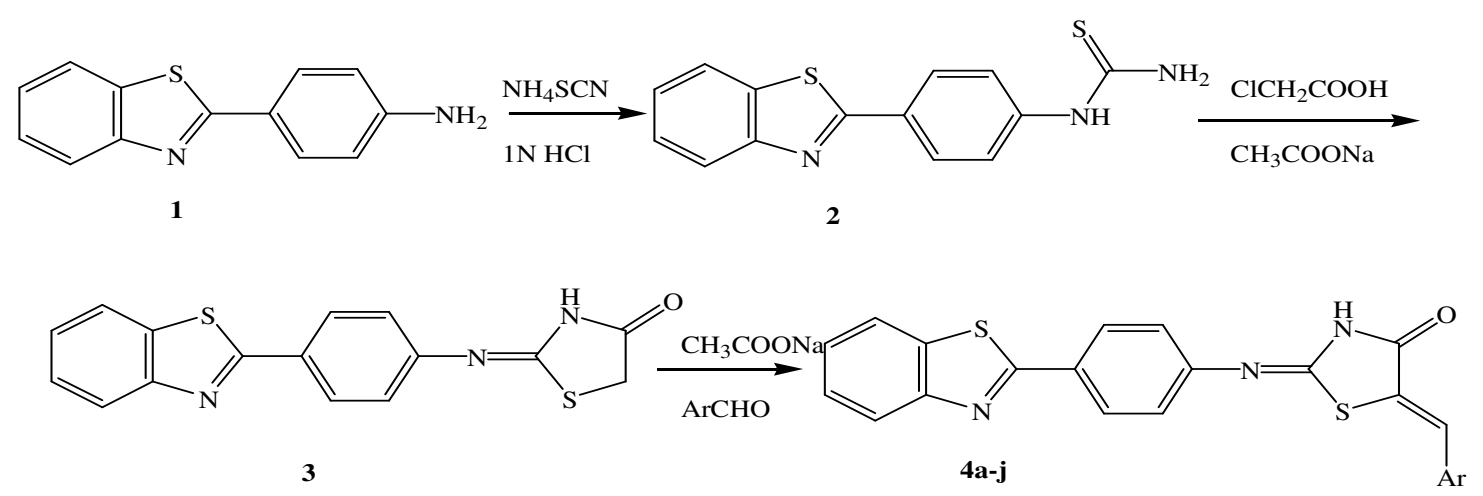

Where, Ar = 4-chlorophenyl, 2-chlorophenyl, 4-methylphenyl, 2-methylphenyl, 4-methoxyphenyl, 3methoxyphenyl, 4-bromophenyl, 2-bromophenyl, 4-fluorophenyl, phenyl

Scheme-1: Synthesis of 2-(4-(benzo[d]thiazol-2-yl) phenylimino) thiazolidin-4-one and 2-(4-(benzo[d]thiazol-2-yl) phenylimino)-5-arylidenethiazolidin-4-ones

\section{Synthesis of 1-(4-(benzo[d]thiazol-2-yl) phenyl) thiourea (2)}

A mixture of 4-(benzo[d]thiazol-2-yl) benzenamine (1) $(0.01 \mathrm{mmol})$ and ammonium thioacyanate $(0.01$ $\mathrm{mmol})$ in $1 \mathrm{~N} \mathrm{HCl}(20 \mathrm{~mL})$ was refluxed for about $6 \mathrm{~h}$ at $80^{\circ} \mathrm{C}$. The reaction completion was monitored by TLC. After completion of the reaction, ethanol is evaporated completely under reduced pressure. The resulting crude compound was dissolved in ethyl acetate $(20 \mathrm{~mL})$, washed with water $(2 \mathrm{X} 20 \mathrm{~mL})$, the organic layer is then dried with $\mathrm{Na}_{2} \mathrm{SO}_{4}$. After evaporation of the solvent, crude compound was further purified by column chromatography by using 60-120 mesh silica, eluted with Methanol in DCM (2-5\%), to afford the product as light brown solid (130mg, 41.5\%). Compound thus obtained, was characterized by spectroscopic methods: ${ }^{1} \mathrm{H}$ NMR (DMSO-d $\left.{ }_{6}\right) \delta=7.82(\mathrm{~d}, 2 \mathrm{H}), 7.42(\mathrm{t}, 2 \mathrm{H}), 7.22(\mathrm{brs}, 1 \mathrm{H}), 7.08(\mathrm{~m}, 4 \mathrm{H})$, 6.42 (brs, 2H); Mass $m / z 286[\mathrm{M}+\mathrm{H}]$. Related spectra are presented in Fig.-1 to 3.

\section{Synthesis of 2-(4-(benzo[d]thiazol-2-yl)phenylimino)thiazolidin-4-one (3)}

To a solution of 1-(4-(benzo[d]thiazol-2-yl) phenyl thiourea (2) $(0.001 \mathrm{mmol})$ in absolute ethanol, chloroacetylchloride $(0.001 \mathrm{mmol})$ and sodium acetate were added and refluxed for $8 \mathrm{hr}$. Progress of the reaction was monitored by TLC. After completion of the reaction, the reaction was concentrated, cooled and poured into crushed ice, and then filtered. The solid obtained was purified by recrystalization, and characterised by specroscopic methods: ${ }^{1} \mathrm{H}$ NMR $\left(\right.$ DMSO-d $\left._{6}\right) \delta=7.84(\mathrm{~d}, 2 \mathrm{H}), 7.44(\mathrm{t}, 2 \mathrm{H}), 7.22$ (brs, $1 \mathrm{H}), 7.10(\mathrm{~m}, 4 \mathrm{H}), 3.48(\mathrm{~d}, 2 \mathrm{H})$; Mass $m / z 326[\mathrm{M}+\mathrm{H}]$. Related spectra are presented in Fig.-4 to 6. 
Synthesis of 2-(4-(benzo[d]thiazol-2-yl)phenylimino)-5-arylidenethiazolidin-4-ones (4a-j)

2-(4-(benzo[d]thiazol-2-yl) phenylimino)thiazolidin-4-one (3) $(0.001 \mathrm{mmol})$ and aldehyde $(0.001 \mathrm{mmol})$ in ethanol containing a few drops of pyridine are refluxed for 5-6 hours. It was then cooled, concentrated and poured into crushed ice and filtered. The solid thus obtained was purified by recrystallization from ethanol to get the target compounds (4a-j). Structures of $4(\mathrm{a}-\mathrm{j})$ are assigned on the basis of mass, NMR, $\mathrm{C}^{13} \mathrm{NMR}$, spectroscopic analysis (Fig.1 to 6).

\section{Invitro Antimicrobial assay}

Standard sterilized filter paper disks ( $5 \mathrm{~mm}$ diameter) impregnated with a solution of the test compound in DMSO $(1 \mathrm{mg} / \mathrm{ml})$ was placed on agar plate seeded with the appropriate test organism in triplicate. The Tetracycline was used as standard antibacterial agent and nystatin was used as antifungal agent. DMSO alone was used as control at the same above mentioned concentration. The plates were incubated at $37^{\circ} \mathrm{C}$ for 1-5 days. Antimicrobial activity was determined by measuring the diameter of the zone of inhibition surrounding microbial growth. The compounds that showed significant growth inhibition zones were further evaluated for their MICs.

\section{Minimal inhibitory concentration (MIC) measurement}

The microorganism susceptibility tests in nutrient and potato dextrose broths were used for the determination of MIC. The stock solutions of the tested compounds, Tetracycline and nystatin were prepared in DMSO at concentration of $1000 \mu \mathrm{g} / \mathrm{ml}$ followed by dilutions at concentrations of $(250-25 \mu \mathrm{g} / \mathrm{ml})$. The microorganism suspensions were inoculated into the different concentrations of corresponding compounds and control experiments. These were incubated at $37^{\circ} \mathrm{C}$ for $1-5$ days for MIC determination. Following bacteria and fungi are selected to study the antimicrobial activity of the compounds, and the zone of inhibition is represented in millimeters.

Sp1. Staphylococcus aureus - coccus, gram positive (+), causes toxic shock syndrome (TSS). Sp2. Klebsiella pneumoniae -rod shape or bacilli, gram negative (-), causes pneumonia Sp3. Proteus mirablis gram negative (-) bacteria.; Sp4. Fusarium Chlamydo sporium - fungi. Sp5 Macrophomina phaseolina - fungi.

\section{RESULTS AND DISCUSSION}

4-(benzo[d]thiazol-2-yl)benzenamine (1) reacts with ammonium thiocyanate in presence of Hydrochloric acid to give 1-(4-(benzo[d]thiazol-2-yl)phenyl)thiourea $(2)^{22}$ which on reaction with Chloroacetylchloride offer 2-(4-(benzo[d]thiazol-2-yl)phenylimino)thiazolidin-4-one (3). ${ }^{\mathbf{2 3}}$ When compound $\mathbf{3}$ is treated with different aryl aldehydes afforded 2-(4-(benzo[d]thiazol-2-yl) phenylimino)-5-arylidenethiazolidin-4-ones $(\mathbf{4 a - j})^{\mathbf{2 4}}$ in good yields with reasonably moderate reaction times.

Table.1: Synthesis of 2-(4-(benzo[d]thiazol-2-yl) phenylimino) -5-arylidenethiazolidin-4-ones (4a-j).

\begin{tabular}{l|l|l|l|l|l|l}
\hline Entry & Ar in Ar-CHO & $\begin{array}{l}\text { R.T. } \\
(\mathrm{hr})\end{array}$ & $\begin{array}{l}\text { Yeild } \\
(\%)\end{array}$ & $\begin{array}{l}\text { Physical } \\
\text { state }\end{array}$ & $\begin{array}{l}\text { M.P/B.P } \\
\left(\mathrm{C}^{\circ}\right)\end{array}$ & $\begin{array}{l}\text { M.W. } \\
(\mathrm{Cal})\end{array}$ \\
\hline $4 \mathrm{a}$ & 4-chlorophenyl & 6 & 80 & Liquid & $177-179$ & 447 \\
\hline $4 \mathrm{~b}$ & 2- chlorophenyl & 6 & 75 & Liquid & $180-182$ & 447 \\
\hline $4 \mathrm{c}$ & 4-methylphenyl & 4 & 79 & Solid & $184-186$ & 427 \\
\hline $4 \mathrm{~d}$ & 2-methylphenyl & 5 & 76 & Solid & $175-177$ & 427 \\
\hline $4 \mathrm{e}$ & 4-methoxyphenyl & 4 & 78 & Liquid & $189-191$ & 443 \\
\hline $4 \mathrm{f}$ & 3-methoxyphenyl & 5 & 72 & Solid & $174-176$ & 443 \\
\hline $4 \mathrm{~g}$ & 4-bromophenyl & 6 & 70 & Liquid & $183-186$ & 491 \\
\hline $4 \mathrm{~h}$ & 2-bromophenyl & 5 & 70 & Liquid & $188-190$ & 491 \\
\hline $4 \mathrm{i}$ & 4-fluorophenyl & 7 & 69 & Liquid & $186-189$ & 429 \\
\hline $4 \mathrm{j}$ & Phenyl & 5 & 72 & Liquid & $171-173$ & 431 \\
\hline
\end{tabular}


Data compiled in Table -1 depict the reaction times (R.T), yields (\%) and physical data for 2-(4(benzo[d]thiazol-2-yl) phenylimino) -5-arylidenethiazolidin-4-one derivatives (4a-j). Presented data indicate that reaction times (R.T) for electron donating (methyl and methoxy) groups are generally less than those observed for electron withdrawing (Flouro, chloro, and bromo) groups.

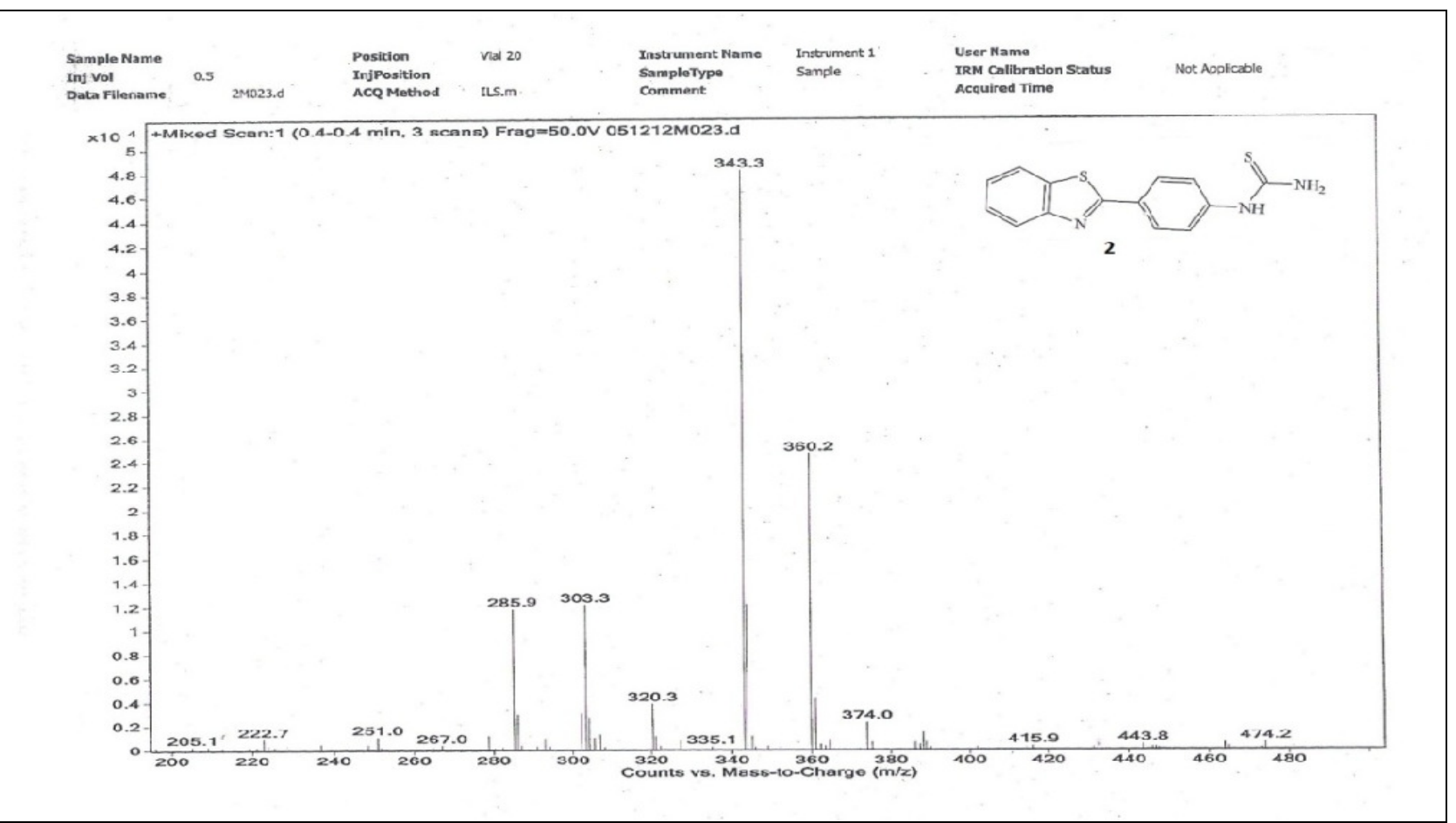

Fig.-1: Mass Spectrum of 1-(4-(benzo[d]thiazol-2-yl) phenyl) thiourea (2)

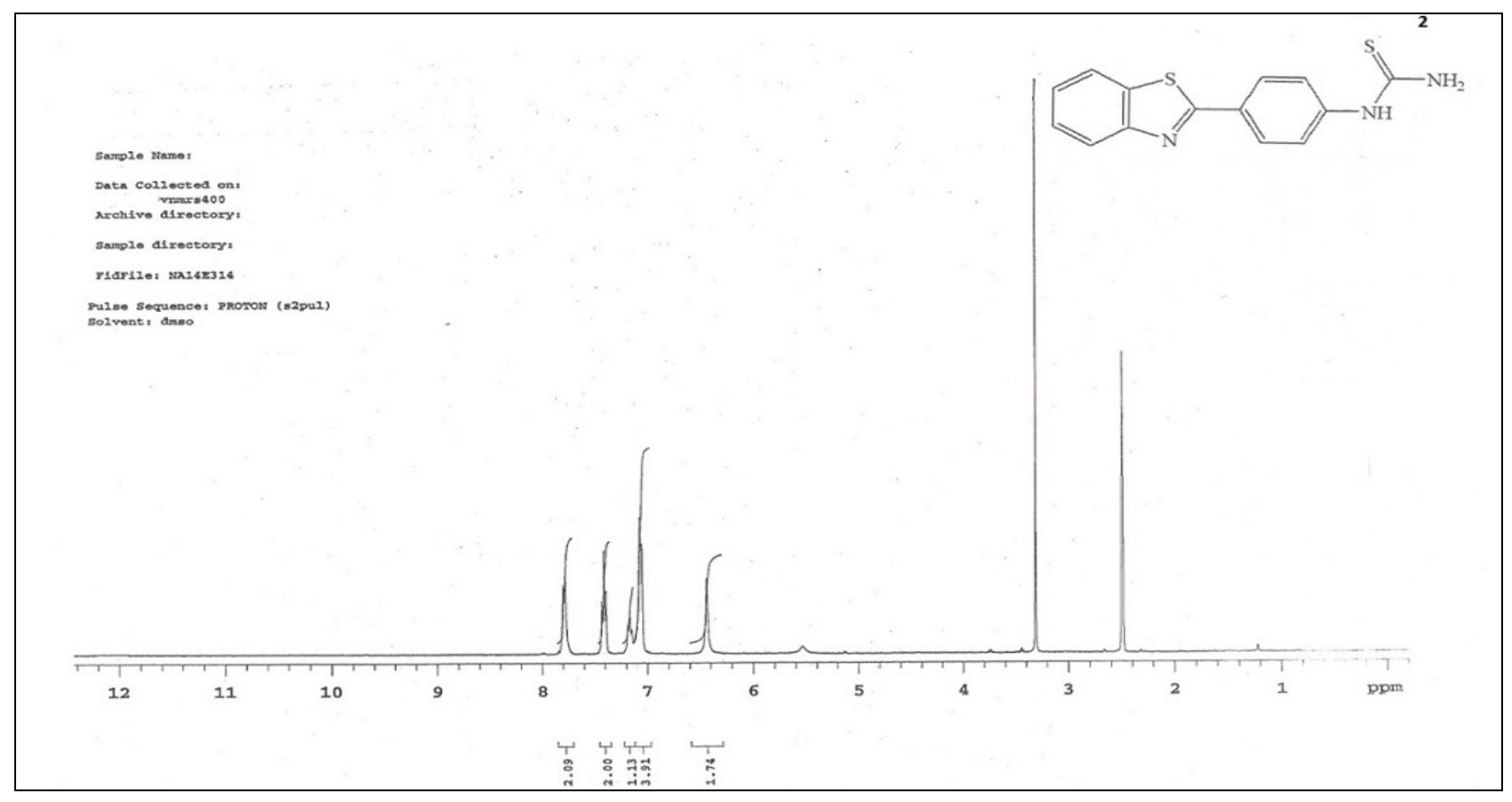

Fig.-2: NMR Spectrum of 1-(4-(benzo[d]thiazol-2-yl) phenyl) thiourea (2) 
Reaction times were found to decrease with an introduction of electron donation groups. Structures of (4a-j) were assigned on the basis of elemental analysis, mass, NMR and C-13 NMR spectroscopic data.

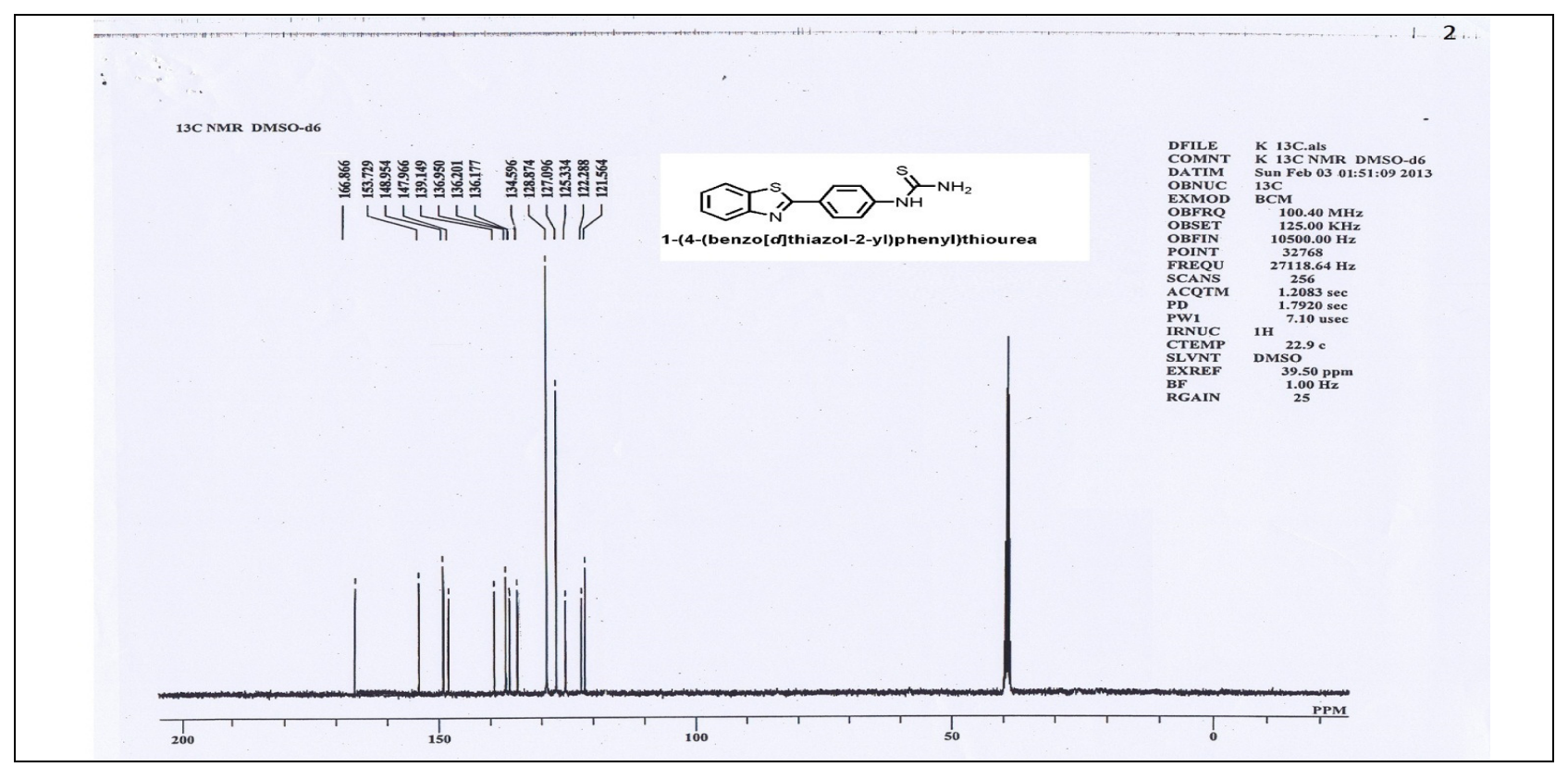

Fig.-3: C-13 NMR Spectrum of 1-(4-(benzo[d]thiazol-2-yl) phenyl) thiourea (2)

To a solution of 1-(4-(benzo[d]thiazol-2-yl)phenyl)thiourea (2) $(0.001 \mathrm{mmol})$ in absolute ethanol, chloroacetylchloride $(0.001 \mathrm{mmol})$ and sodium acetate were added and refluxed for $8 \mathrm{hr}$. Progress of the reaction was monitored by TLC. After completion of the reaction, the reaction was concentrated, cooled and poured into crushed ice, and then filtered. The solid obtained was purified by recrystalization, and characterised by specroscopic methods: ${ }^{1} \mathrm{H}$ NMR (DMSO- $\left.\mathrm{d}_{6}\right) \delta=7.84(\mathrm{~d}, 2 \mathrm{H}), 7.44(\mathrm{t}, 2 \mathrm{H}), 7.22$ (brs, $1 \mathrm{H}), 7.10(\mathrm{~m}, 4 \mathrm{H}), 3.48(\mathrm{~d}, 2 \mathrm{H})$; Mass $m / z 326[\mathrm{M}+\mathrm{H}]$. Corresponding spectra are shown in Fig.- 4 to 6.

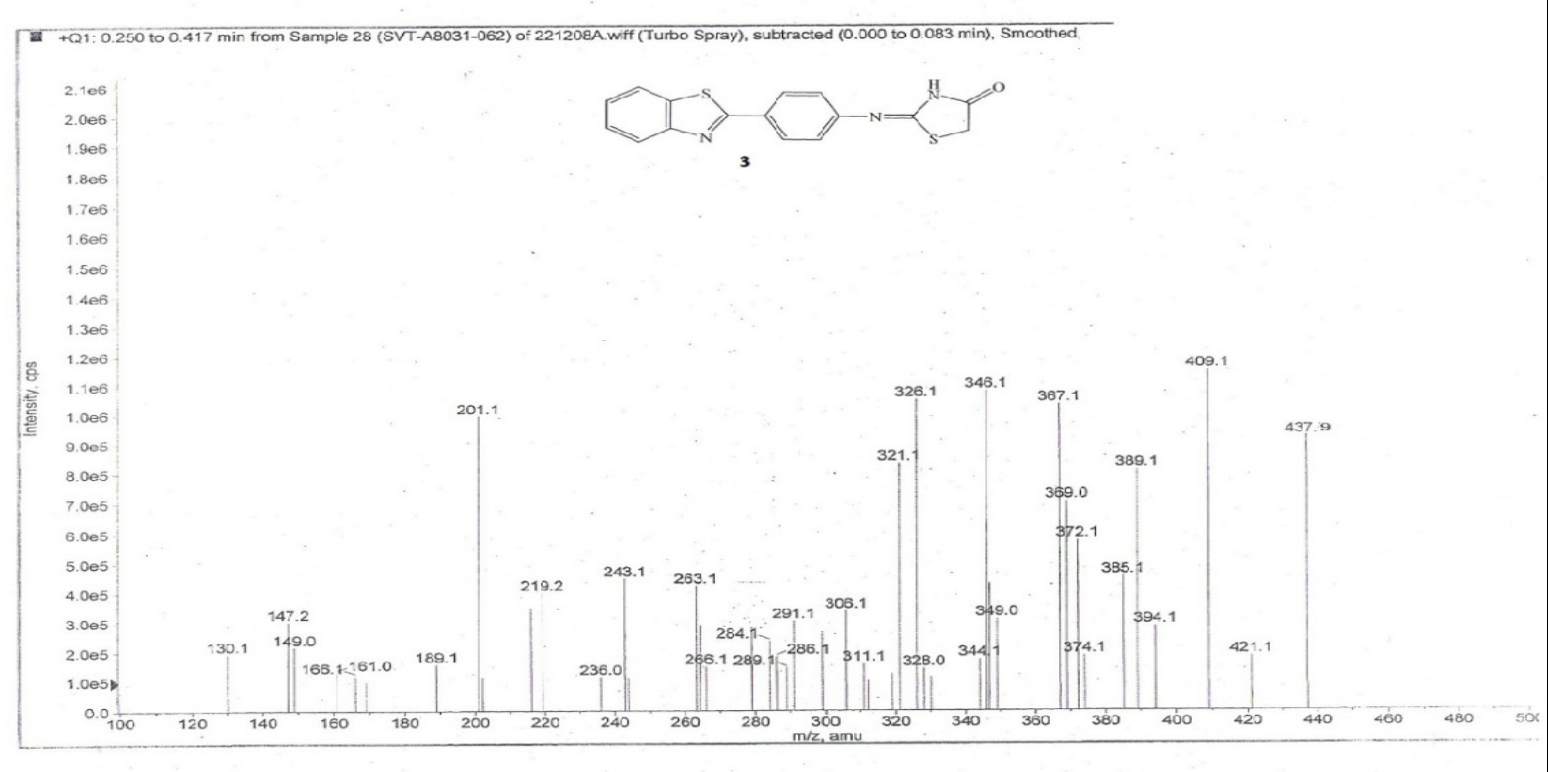

Fig.-4: Mass Spectrum of 2-(4-(benzo[d]thiazol-2-yl) phenylimino) thiazolidin-4-one (3) 


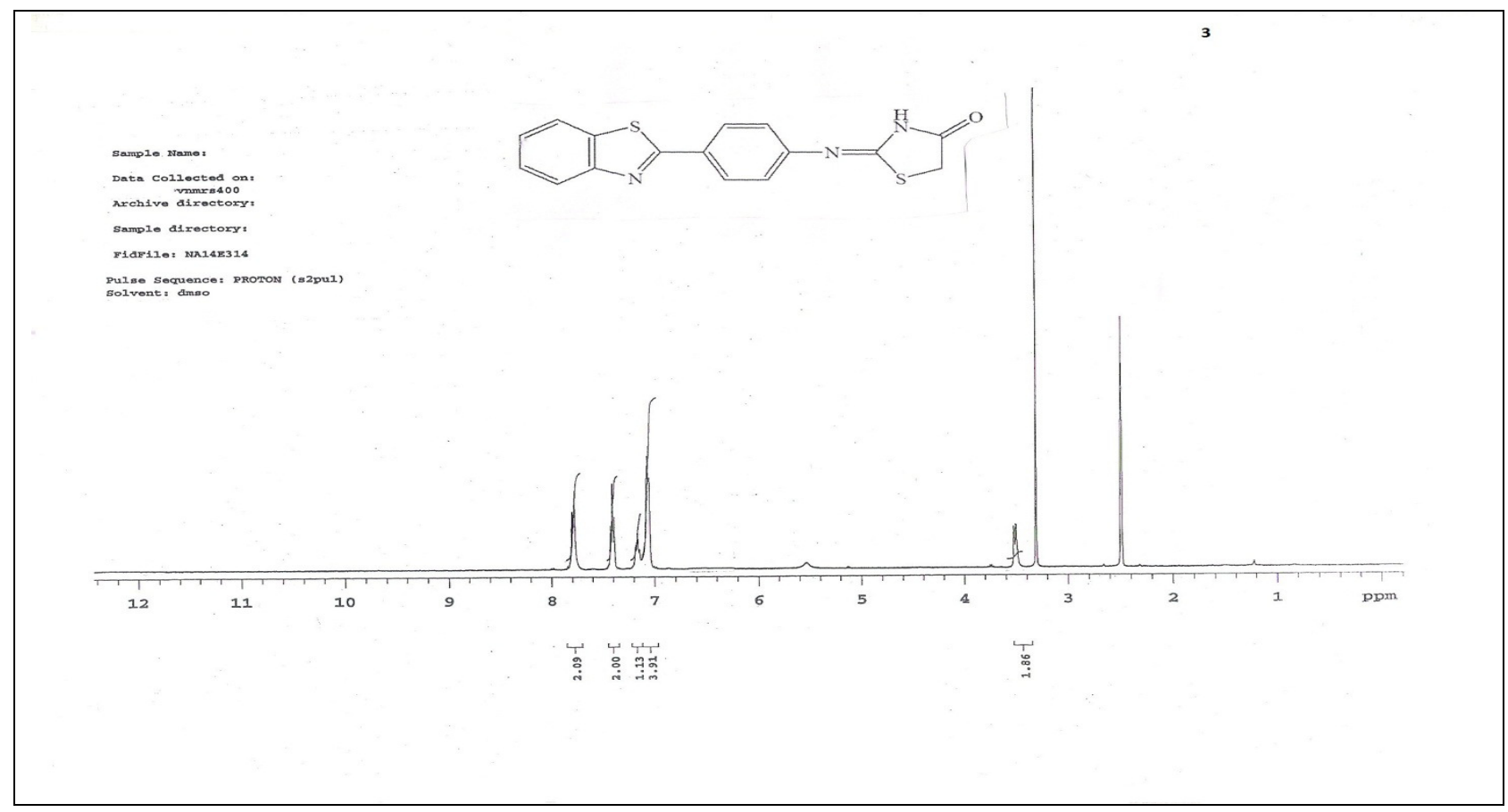

Fig.-5: NMR Spectrum of 2-(4-(benzo[d]thiazol-2-yl) phenylimino) thiazolidin-4-one (3)

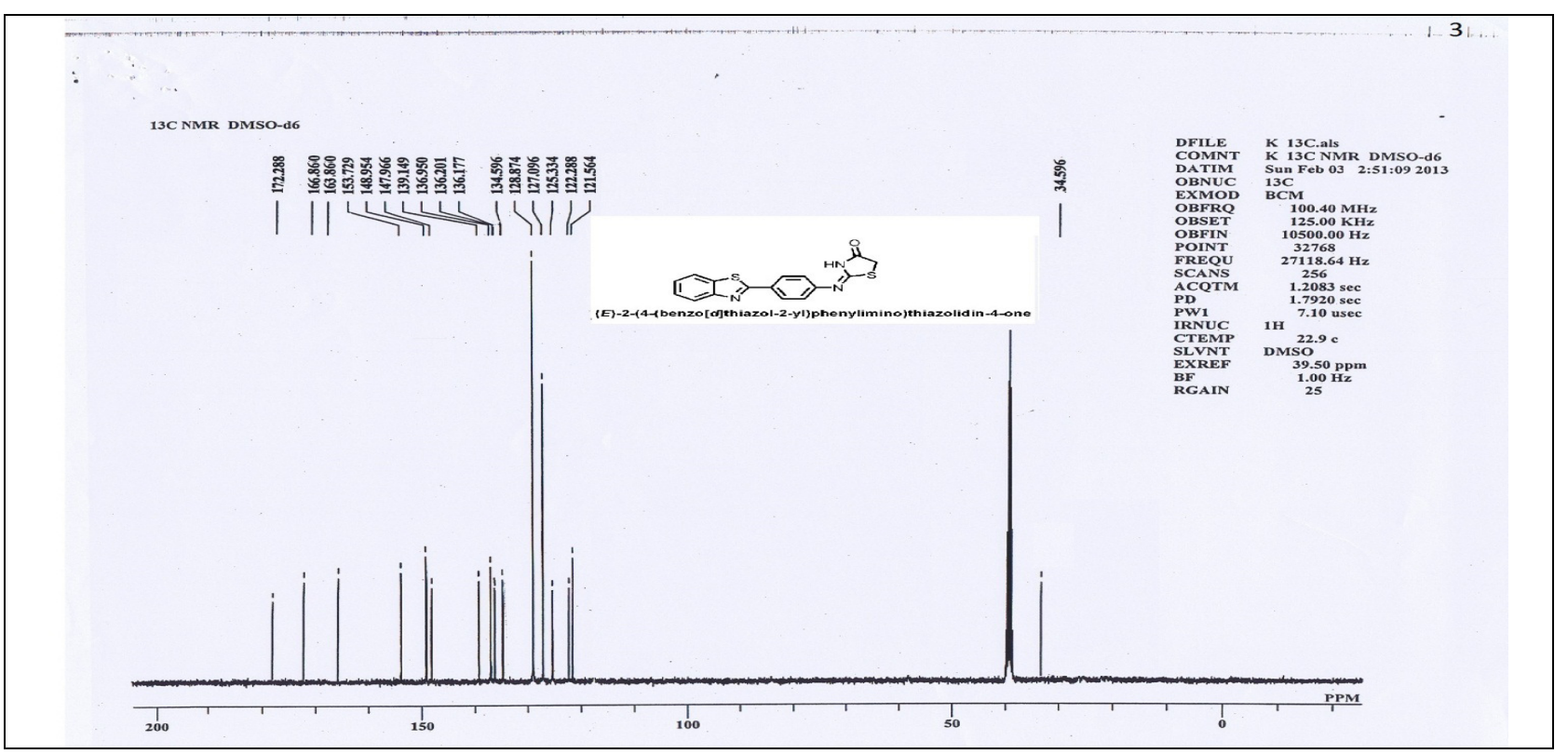

Fig.-6: C-13 NMR Spectrum of 2-(4-(benzo[d]thiazol-2-yl) phenylimino) thiazolidin-4-one (3)

Synthesis of 2-(4-(benzo[d]thiazol-2-yl)phenylimino)-5-arylidenethiazolidin-4-ones (4a-j) was performed using 2-(4-(benzo[d]thiazol-2-yl)phenylimino)thiazolidin-4-one (3) $(0.001 \mathrm{mmol})$ and aldehyde $(0.001$ $\mathrm{mmol}$ ) in ethanol containing a few drops of pyridine under reflux for 5-6 hours. The resultant entity was then cooled, concentrated and poured into crushed ice and filtered. The solid thus obtained was purified by recrystallization from ethanol to get the target compounds (4a-j). Structures of 4(a-j) are assigned on the basis of mass, NMR, $\mathrm{C}^{13} \mathrm{NMR}$, spectroscopic analysis. As specific examples mass, NMR and C-13 
spectra of certain synthesized compounds, are interpreted using the corresponding spectroscopic sketches (Fig. -7 to 12 ).

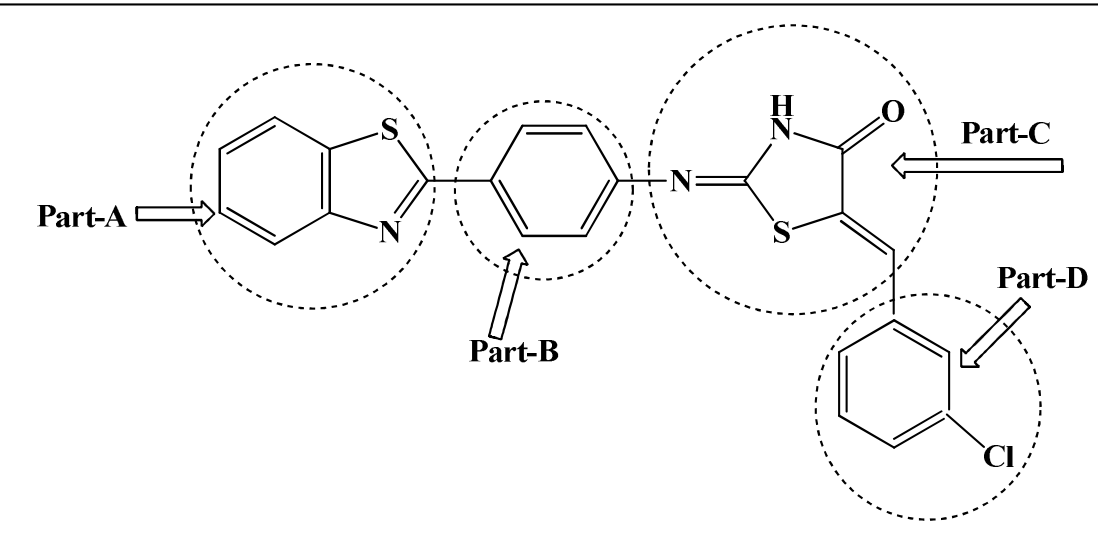

4(a):2-(4-(benzo[d]thiazol-2-yl)phenylimino)-5-phenylidenethiazolidin-4-one

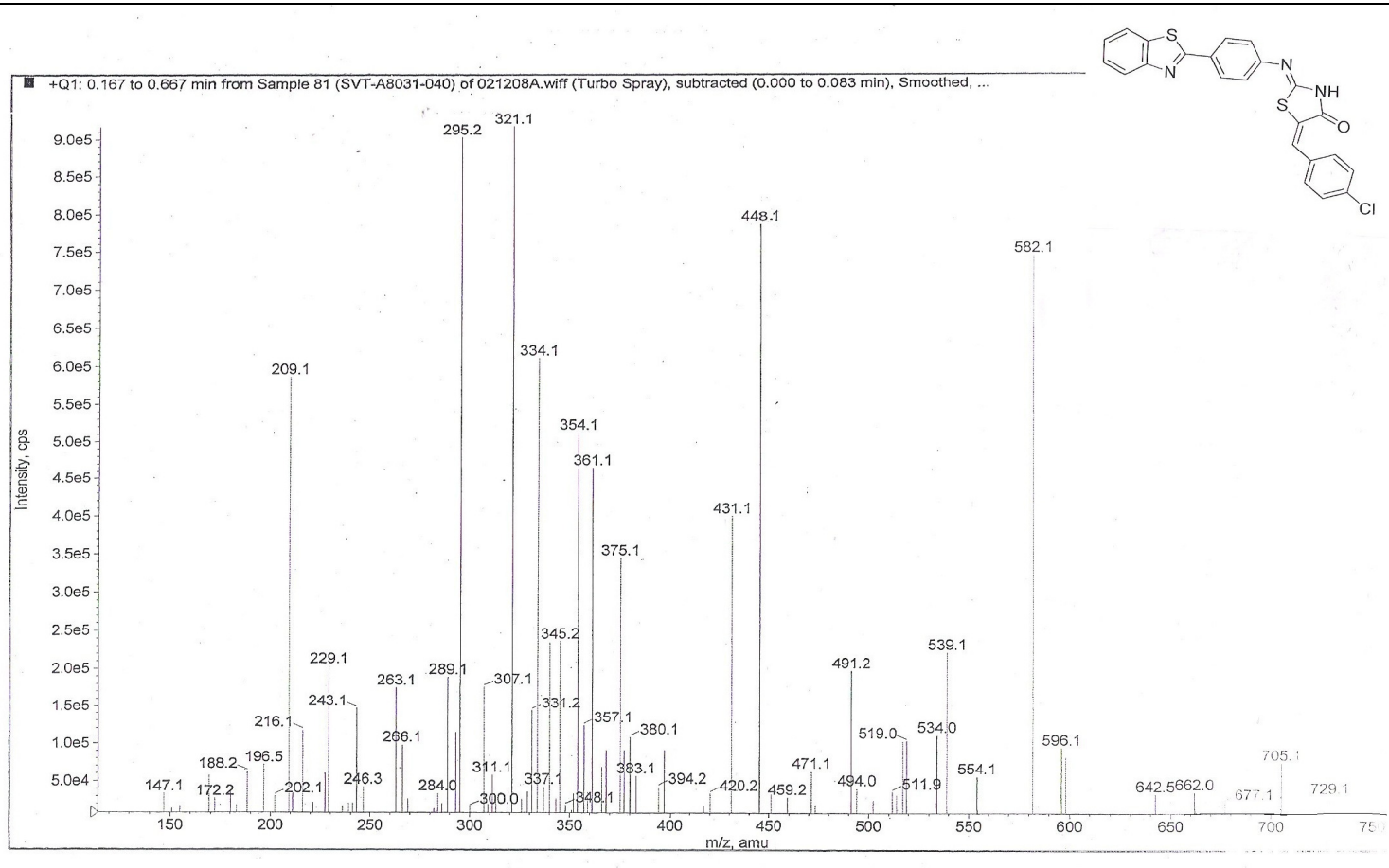

Mass spectrum of (4a)

Fig-7: Mass spectrum of (4a)

Mass spectrum of compound (4a) shows $(M+1)$ peak at 448. This agrees well with molecular ion peak (which should have been at 447), and also in accordance nitrogen rule indicating the presence of odd number of nitrogens. Peak at 321 is probably due to loss of - $\mathrm{PhCl}$ moiety from parent compound. Another important peak located at 209.1 might be due to the loss of Benzothiazole moiety (part-A) from parent compound. NMR spectrum of (4a) shows a multiplet at 6.8-8.2 $\delta$, which could be accounted for all aromatic protons corresponding to Parts-A,B, C and D of the molecule. Singlet peaks observed at 2.5 and $3.3 \delta$ could be due to the presence of $-\mathrm{C}-\mathrm{H}$ proton in part- $\mathrm{C}$ and $-\mathrm{C}-\mathrm{NH}$ proton in part-C respectively. 
RASĀYAN $J$. Chem.

Vol. 10 | No. 2 |319-332 | April - June | 2017

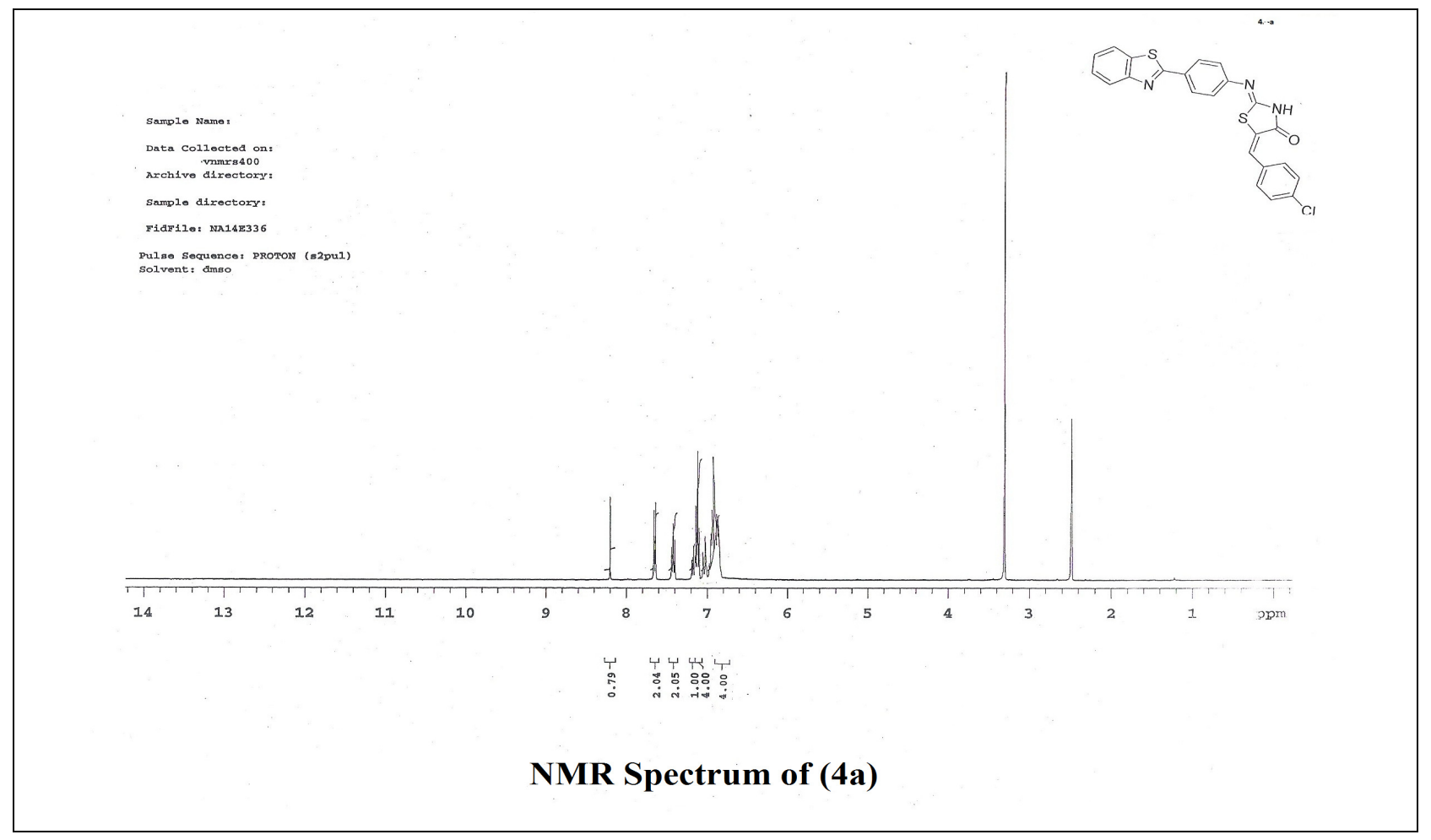

Fig.-8: NMR spectrum of (4a)

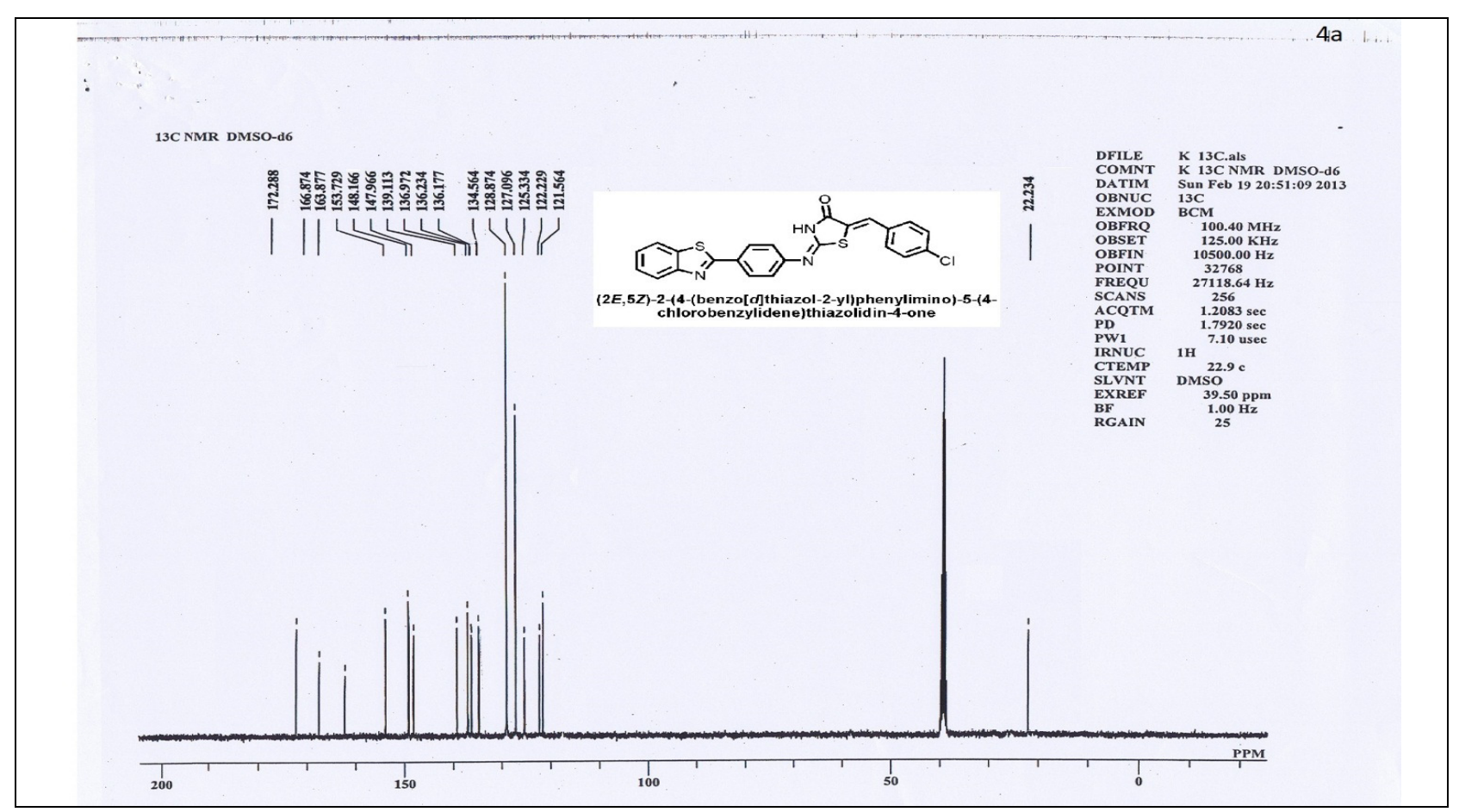

Fig.-9: C-13 NMR spectrum of (4a)

$C^{13}$ NMR Spectrum of (4a and $\left.4 b\right)$

$\mathrm{C}^{13} \mathrm{NMR}$ Spectrum of (4a) depicted all aromatic carbons of parts-A, B and D of the molecule in the range 125-148 ppm, while thiazole carbon of (Part-A) appeared at 153ppm as singlet. The carbon of thiazoli- 
dine ring attached to sulfur and oxygen atoms of 5 member ring (of part-C) appeared at $122 \mathrm{ppm}$ and the carbon connecting between part- $\mathrm{C}$ and part- $\mathrm{D}$ is seen at $121 \mathrm{ppm}$ while the peaks corresponding to $-\mathrm{C}=\mathrm{N}$ carbon and keto- carbon (part-C) appeared at $166 \mathrm{ppm}$ and 172ppm respectively.

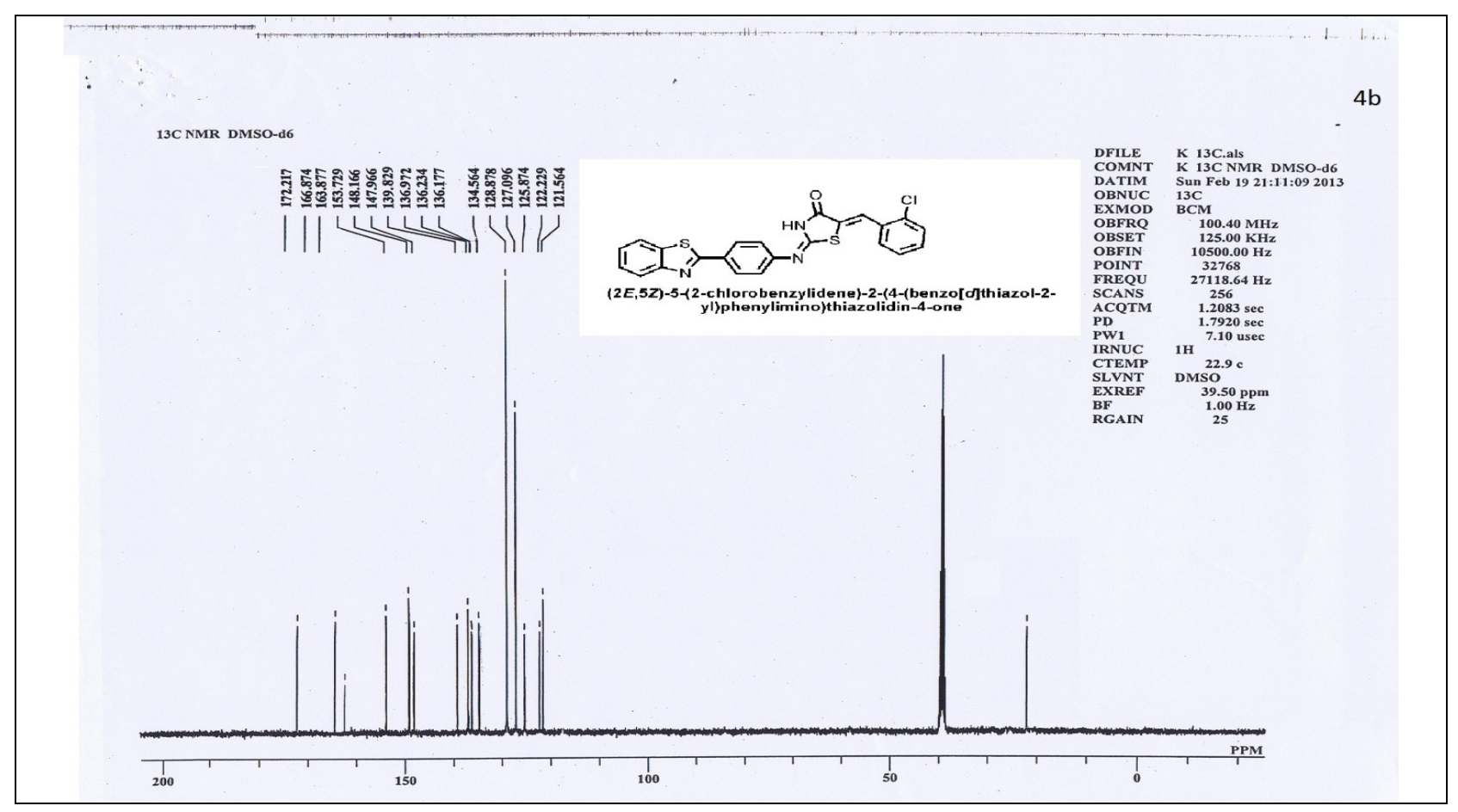

Fig.-10: C-13 NMR spectrum of (4b)

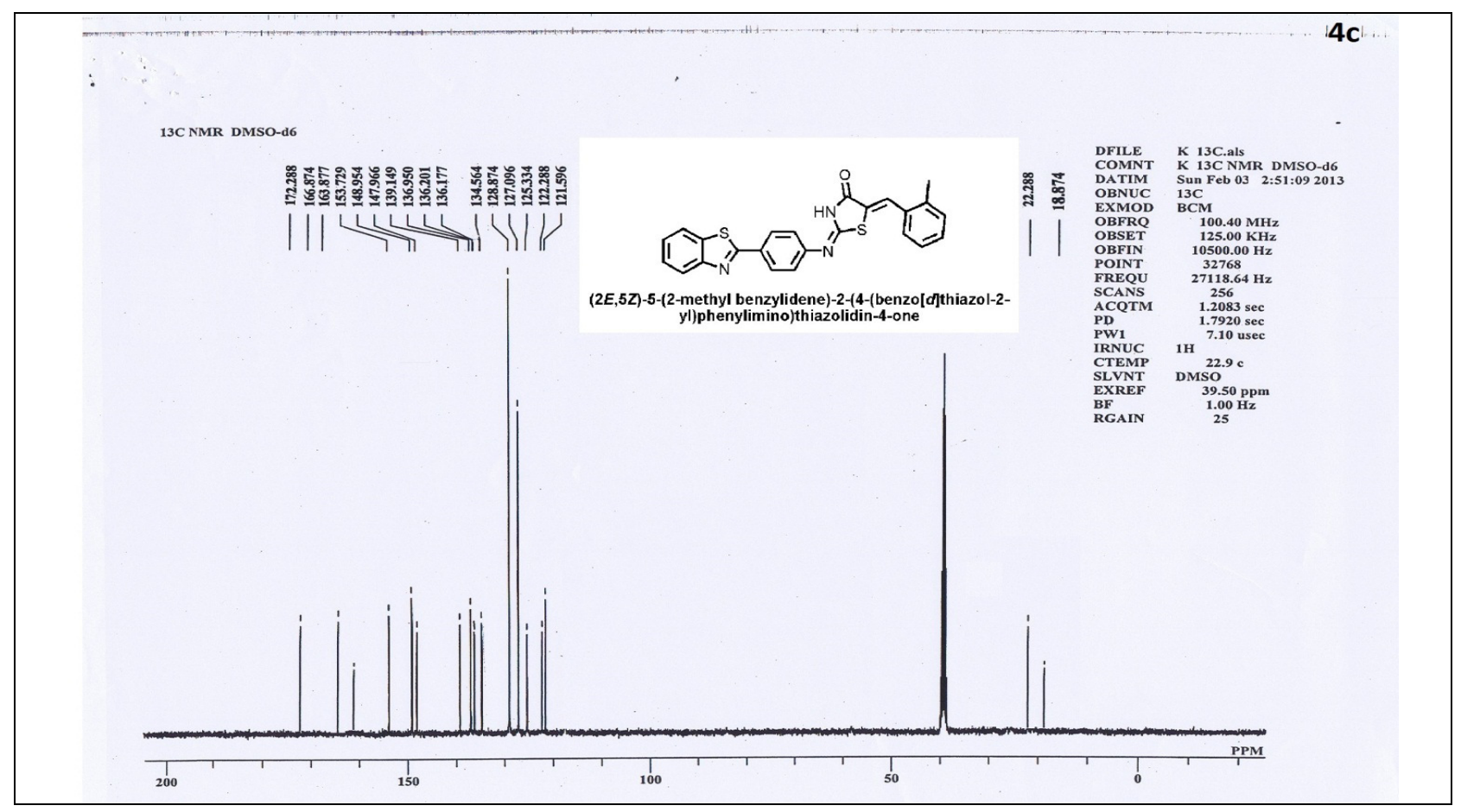

Fig.-11: C-13 NMR spectrum of (4c) 
RASĀYAN J. Chem.

Vol. 10 | No. 2 |319 -332 | April - June | 2017

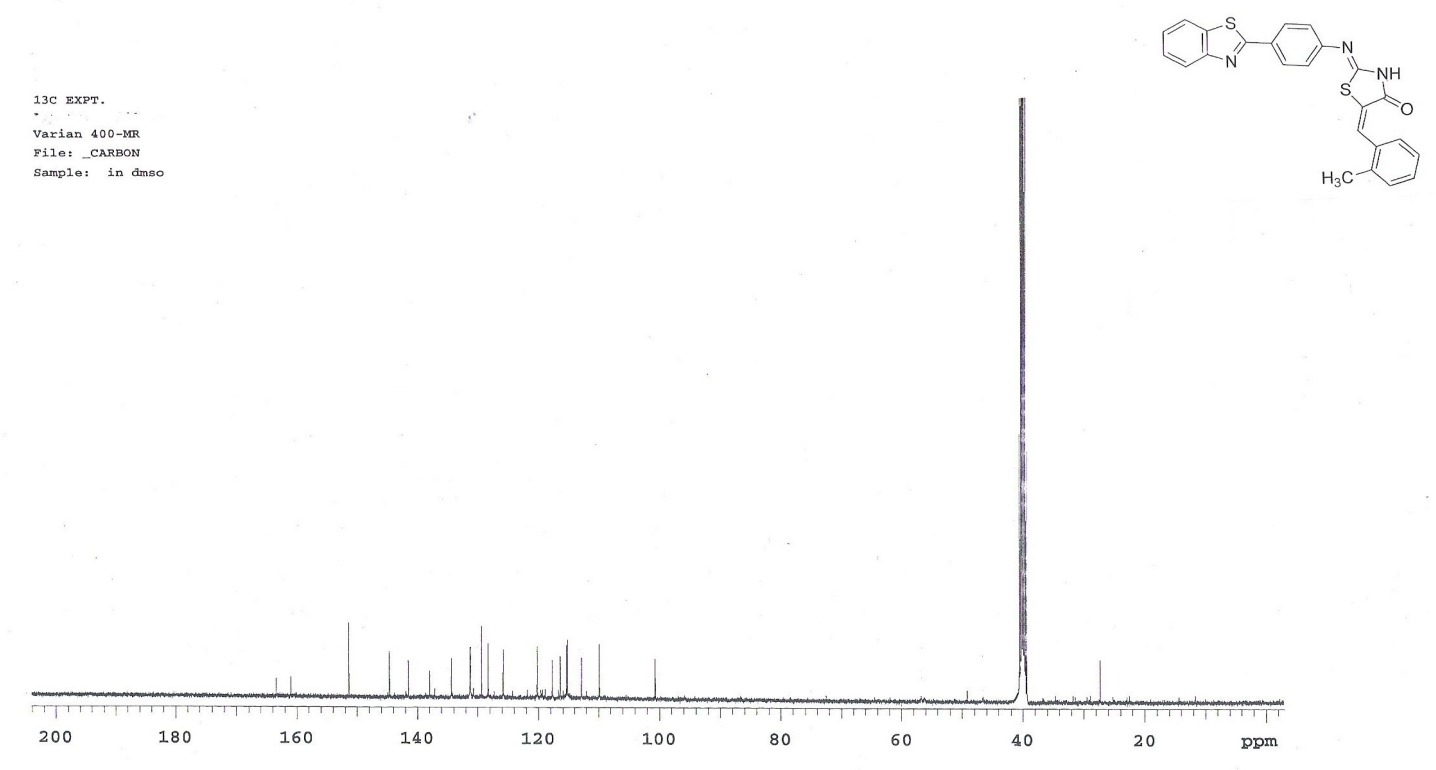

\section{C-13 NMR Spectrum of (4 d)}

Fig.-12: C-13 NMR Spectrum of (4d)

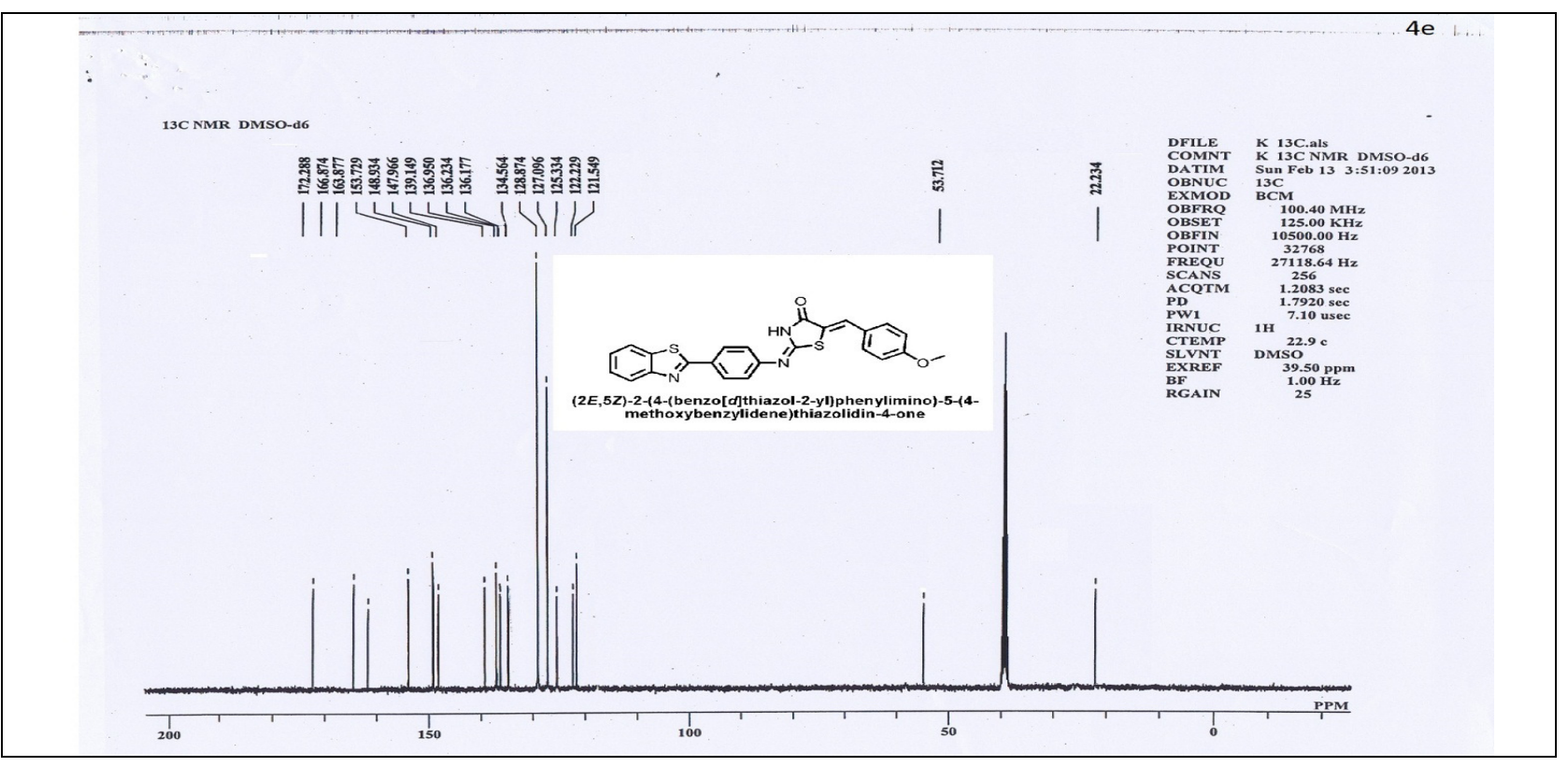

$C^{13}$ NMR Spectrum of $(4 c$ and $4 d)$

Fig.-13: C-13 NMR Spectrum of (4e)

$C^{13}$ NMR Spectrum of (4c) depicted all aromatic carbons of parts-A, B and D of the molecule in the range $125-148 \mathrm{ppm}$, while thiazole carbon of (Part-A) appeared at $153 \mathrm{ppm}$ as singlet. The methyl group attached to the part-D of the molecule is seen at $19 \mathrm{ppm}$. The carbon of thiazolidine ring attached to sulfur and oxygen atoms of 5 member ring (of part-C) appeared at $122 \mathrm{ppm}$ and the carbon connecting between part- $\mathrm{C}$ and part-D is seen at $121 \mathrm{ppm}$ while the peaks corresponding to $-\mathrm{C}=\mathrm{N}$ carbon and keto- carbon (part-C) appeared at $166 \mathrm{ppm}$ and $172 \mathrm{ppm}$ respectively. 
$\mathrm{C}^{13}$ NMR Spectrum of (4d) depicted all aromatic carbons of parts-A, B and D of the molecule in the range 112-145 ppm, while thiazole carbon of (Part-A) appeared at $152 \mathrm{ppm}$ as singlet. Directly connecting carbons of the part - $\mathrm{C}$ to part-D appeared at $100 \mathrm{ppm}$. Carbon attached to sulfur and oxygen atoms of 5 member ring (of part-C) appeared at $110 \mathrm{ppm}$, while the peaks corresponding to $-\mathrm{C}=\mathrm{N}$ carbon and ketocarbon (part-C) appeared at $161 \mathrm{ppm}$ and $164 \mathrm{ppm}$ respectively. Finally, the methyl carbon $\left(-\mathrm{CH}_{3}\right.$ carbon) attached to phenyl group in part $-\mathrm{D}$ of the molecule is indicated at $27 \mathrm{ppm}$.

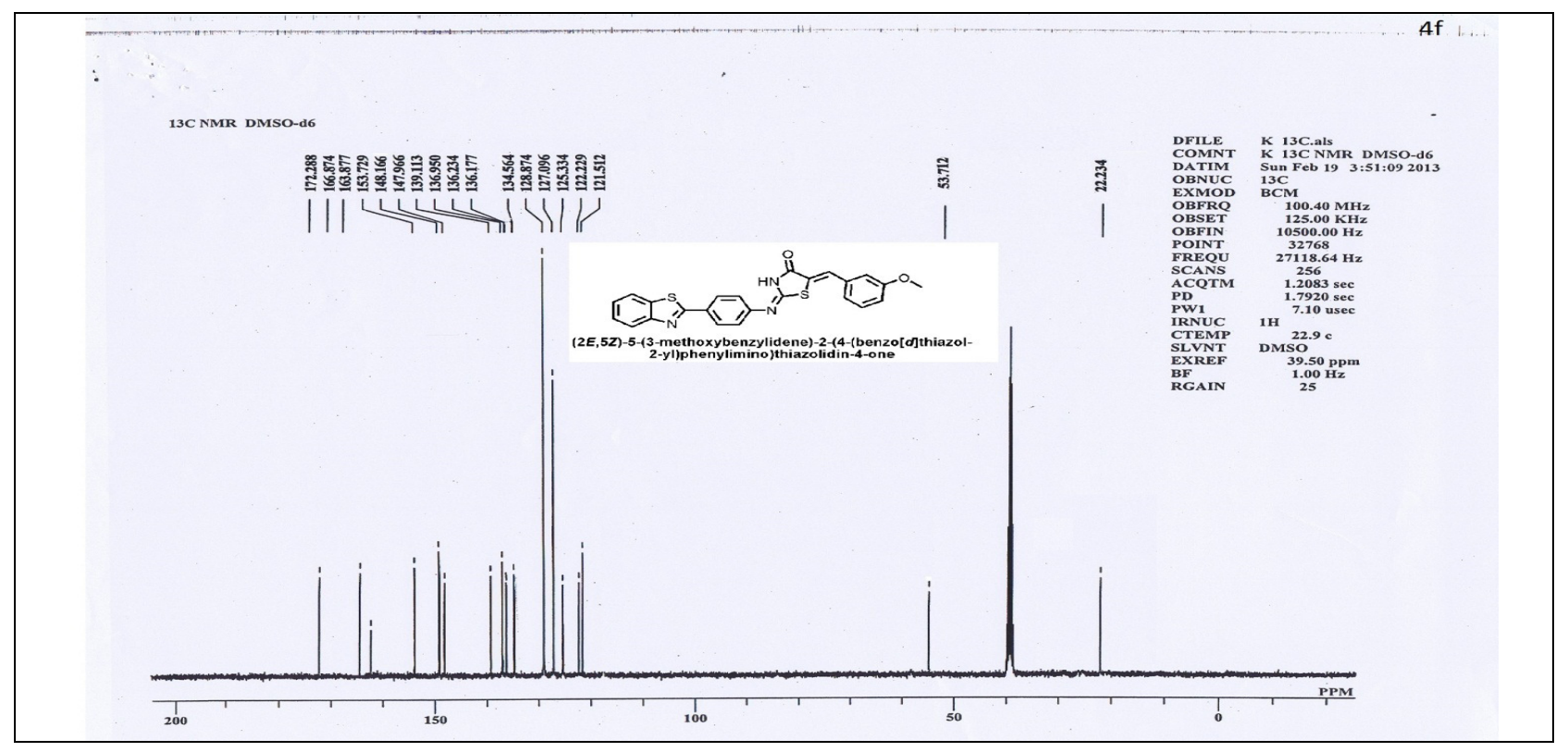

$C^{13}$ NMR Spectrum of (4e and $\left.4 f\right)$

Fig.-14: C-13 NMR Spectrum of (4f)

$\mathrm{C}^{13}$ NMR Spectrum of (4e) depicted all aromatic carbons of parts-A, B and D of the molecule in the range $125-148 \mathrm{ppm}$, while thiazole carbon of (Part-A) appeared at $153 \mathrm{ppm}$ as singlet. The methoxy group attached to the part-D of the molecule is seen at 55ppm. The carbon of thiazolidine ring attached to sulfur and oxygen atoms of 5 member ring (of part-C) appeared at $122 \mathrm{ppm}$ and the carbon connecting between part- $\mathrm{C}$ and part- $\mathrm{D}$ is seen at $121 \mathrm{ppm}$ while the peaks corresponding to $-\mathrm{C}=\mathrm{N}$ carbon and keto- carbon (part-C) appeared at $166 \mathrm{ppm}$ and $172 \mathrm{ppm}$ respectively.

Spectroscopic data for the derivatives $4(\mathrm{a}-\mathrm{j})$ are shown below 2-(4-(benzo[d]thiazol-2-yl)phenylimino)-5-phenylidene) thiazolidin-4-one(4a)

${ }^{1} \mathrm{H}$ NMR (DMSO-d $\left.\mathrm{d}_{6}\right) \delta=8.20(\mathrm{~s}, 1 \mathrm{H}), 2.5(\mathrm{~s} 1 \mathrm{H}) 3.3(\mathrm{~s}, 2 \mathrm{H}), 4.26(\mathrm{t}, 2 \mathrm{H}), 7.43$ (brs, 1H), $7.66(\mathrm{~d} \mathrm{C}-\mathrm{NH})$, $8.2(\mathrm{~m}, 4 \mathrm{H}) ; \mathrm{C}^{13} \mathrm{NMR}$ (DMSO-d $\left.\mathrm{d}_{6}\right): \delta 125-148 \delta 153 \mathrm{ppm} \delta 122, \delta 121 \mathrm{ppm}, \delta 166 \mathrm{ppm}$ and $\delta 172 \mathrm{ppm}$; Mass $m / z$ 447 [M+H]

\section{2-(4-(benzo[d]thiazol-2-yl)phenylimino)-5-(2-chlorobenzylidene) thiazolidin-4-one(4b)}

${ }^{1} \mathrm{H}$ NMR (DMSO-d $\left.\mathrm{d}_{6}\right) \delta=8.22(\mathrm{~s}, 1 \mathrm{H}), 7.76(\mathrm{~d}, 2 \mathrm{H}), 7.46(\mathrm{t}, 2 \mathrm{H}), 7.23($ brs, $1 \mathrm{H}), 7.13(\mathrm{~m}, 4 \mathrm{H}), 6.96(\mathrm{~m}$, $4 \mathrm{H}$ ); $\mathrm{C}^{13} \mathrm{NMR}$ (DMSO-d 6 ): $\delta 125-148 \delta 153 \mathrm{ppm} \delta 122, \delta 121 \mathrm{ppm}, \delta 166 \mathrm{ppm}$ and $\delta 172 \mathrm{ppm}$.; Mass $\mathrm{m} / z$ $448[\mathrm{M}+\mathrm{H}]$

\section{2-(4-(benzo[d]thiazol-2-yl)phenylimino)-5-(4-methylbenzylidene) thiazolidin-4-one(4c)}

${ }^{1} \mathrm{H}$ NMR (DMSO-d $\left.\mathrm{d}_{6}\right) \delta=8.23(\mathrm{~s}, 1 \mathrm{H}), 7.78(\mathrm{~d}, 2 \mathrm{H}), 7.47(\mathrm{~d}, 2 \mathrm{H}), 7.24$ (brs, 1H), $7.15(\mathrm{~m}, 4 \mathrm{H}), 7.04(\mathrm{~m}$, 4H), 2.31 (s, 3H); $\mathrm{C}^{13} \mathrm{NMR}$ (DMSO-d $): \delta 125-148 \mathrm{ppm}, \delta 153 \mathrm{ppm}, \delta 19 \mathrm{ppm}, \delta 122 \mathrm{ppm}, \delta 121 \mathrm{ppm}, \delta$ $166 \mathrm{ppm}$ and $\delta$ 172ppm.; Mass $m / z 428[\mathrm{M}+\mathrm{H}]$ 
2-(4-(benzo[d]thiazol-2-yl)phenylimino)-5-(2-methylbenzylidene)thiazolidin-4-one(4d)

${ }^{1} \mathrm{H}$ NMR $\left(\right.$ DMSO- $\left._{6}\right) \delta=8.24(\mathrm{~s}, 1 \mathrm{H}), 7.78(\mathrm{~d}, 2 \mathrm{H}), 7.48(\mathrm{~d}, 2 \mathrm{H}), 7.24($ brs, $1 \mathrm{H}), 7.18(\mathrm{~m}, 4 \mathrm{H}), 7.04(\mathrm{~m}$, $4 \mathrm{H}), 2.31$ (s, 3H); $\mathrm{C}^{13} \mathrm{NMR}$ (DMSO-d $\left.\mathrm{d}_{6}\right): \delta 112-145 \mathrm{ppm}, \delta 152 \mathrm{ppm}, \delta 100 \mathrm{ppm}, \delta 110 \mathrm{ppm}, \delta 161 \mathrm{ppm}, \delta$ 164 ppm, $\delta 27$ ppm.; Mass. $m / z 428[\mathrm{M}+\mathrm{H}]$

\section{2-(4-(benzo[d]thiazol-2-yl)phenylimino)-5-(4-methoxybenzylidene)thiazolidin-4-one(4e)}

${ }^{1} \mathrm{H}$ NMR (DMSO-d $\left.{ }_{6}\right) \delta=8.23(\mathrm{~s}, 1 \mathrm{H}), 7.74(\mathrm{~d}, 2 \mathrm{H}), 7.46(\mathrm{t}, 2 \mathrm{H}), 7.24(\mathrm{brs}, 1 \mathrm{H}), 7.20(\mathrm{~m}, 4 \mathrm{H}), 7.05(\mathrm{~m}$, $4 \mathrm{H}), 3.74$ (s, 3H); $\mathrm{C}^{13} \mathrm{NMR}$ (DMSO-d ${ }_{6}$ ): $\delta 125-148 \mathrm{ppm}, \delta 153 \mathrm{ppm}, \delta 55 \mathrm{ppm}, \delta 122 \mathrm{ppm}, \delta 121 \mathrm{ppm}, \delta$ $166 \mathrm{ppm}$ and $\delta$ 172ppm.; Mass $m / z 444[\mathrm{M}+\mathrm{H}]$

2-(4-(benzo[d]thiazol-2-yl)phenylimino)-5-(3-methoxybenzylidene)thiazolidin-4-one(4f) ${ }^{1} \mathrm{H}$ NMR (DMSO-d $\left.\mathrm{d}_{6}\right) \delta=8.22(\mathrm{~s}, 1 \mathrm{H}), 7.76(\mathrm{~d}, 2 \mathrm{H}), 7.48(\mathrm{t}, 2 \mathrm{H}), 7.26(\mathrm{brs}, 1 \mathrm{H}), 7.22(\mathrm{~m}, 4 \mathrm{H}), 7.06(\mathrm{~m}$, $4 \mathrm{H}), 3.74(\mathrm{~s}, 3 \mathrm{H}) ; \mathrm{C}^{13} \mathrm{NMR}$ (DMSO-d $\left.{ }_{6}\right): \delta 125-148 \mathrm{ppm}, \delta 153 \mathrm{ppm}, \delta 55 \mathrm{ppm}, \delta 122 \mathrm{ppm}, \delta 121 \mathrm{ppm}, \delta$ $166 \mathrm{ppm}$ and $\delta$ 172ppm.; Mass $m / z 444[\mathrm{M}+\mathrm{H}]$

2-(4-(benzo[d]thiazol-2-yl)phenylimino)-5-(4-bromobenzylidene)thiazolidin-4-one(4g)

${ }^{1} \mathrm{H}$ NMR (DMSO-d $\left.\mathrm{d}_{6}\right) \delta=8.24(\mathrm{~s}, 1 \mathrm{H}), 7.78(\mathrm{~d}, 2 \mathrm{H}), 7.48(\mathrm{~m}, 2 \mathrm{H}), 7.28(\mathrm{brs}, 1 \mathrm{H}), 7.20(\mathrm{~m}, 4 \mathrm{H}), 7.10(\mathrm{~m}$, $4 \mathrm{H}) ;$ Mass $m / z 492[\mathrm{M}+\mathrm{H}]$

2-(4-(benzo[d]thiazol-2-yl)phenylimino)-5-(2-bromobenzylidene)thiazolidin-4-one(4h)

${ }^{1} \mathrm{H}$ NMR (DMSO-d $\left.\mathrm{d}_{6}\right) \delta=8.24(\mathrm{~s}, 1 \mathrm{H}), 7.78(\mathrm{~d}, 2 \mathrm{H}), 7.49(\mathrm{~m}, 2 \mathrm{H}), 7.29(\mathrm{brs}, 1 \mathrm{H}), 7.20(\mathrm{~m}, 4 \mathrm{H}), 7.11(\mathrm{~m}$, $4 \mathrm{H}) ;$ Mass $m / z 492[\mathrm{M}+\mathrm{H}]$

\section{2-(4-(benzo[d]thiazol-2-yl)phenylimino)-5-(4-fluorobenzylidene)thiazolidin-4-one(4i)}

${ }^{1} \mathrm{H}$ NMR (DMSO- $\left.\mathrm{d}_{6}\right) \delta=8.24(\mathrm{~s}, 1 \mathrm{H}), 7.79(\mathrm{~m}, 2 \mathrm{H}), 7.48(\mathrm{~m}, 2 \mathrm{H}), 7.24(\mathrm{brs}, 1 \mathrm{H}), 7.14(\mathrm{~m}, 4 \mathrm{H}), 7.01(\mathrm{~m}$, $4 \mathrm{H}) ;$ Mass $m / z 432[\mathrm{M}+\mathrm{H}]$

2-(4-(benzo[d]thiazol-2-yl)phenylimino)-5-benzylidenethiazolidin-4-one(4j)

${ }^{1} \mathrm{H}$ NMR $\left(\right.$ DMSO-d $\left._{6}\right) \delta=8.23(\mathrm{~s}, 1 \mathrm{H}), 7.76(\mathrm{~m}, 2 \mathrm{H}), 7.46(\mathrm{~m}, 2 \mathrm{H}), 7.25$ (brs, 1H), $7.15(\mathrm{~m}, 5 \mathrm{H}), 7.99$ (m, 4H); Mass $m / z 414[\mathrm{M}+\mathrm{H}]$

Minimal inhibitory concentration (MIC) measurement and “in vitro" Antimicrobial assay

The microorganism's susceptibility tests in nutrient and potato dextrose broths were used for the determination of minimal inhibitory concentration (MIC) with tetracycline and nystatin as standards, and observed results are presented in Table-2. Antimicrobial activity was determined by measuring the diameter of the zone of inhibition surrounding microbial growth. The compounds that showed significant growth inhibition zones were further evaluated for their MICs.

Table-2: Biological Screening (Antimicrobial activity)

\begin{tabular}{l|l|l|l|l|l}
\hline \multirow{2}{*}{ Entry } & \multicolumn{4}{|l}{ Zone of inhibition and Species used for activity } \\
\cline { 2 - 6 } & Sp1 & p2 & Sp3 & Sp4 & Sp5 \\
\hline 4 a. & 18 & 12 & 12 & 23 & 18 \\
\hline 4 b. & 21 & 23 & 16 & 14 & 12 \\
\hline 4 c. & 10 & 22 & 14 & 10 & 8 \\
\hline 4 d. & 12 & 23 & 18 & 12 & 10 \\
\hline 4 e. & 11 & 23 & 16 & 10 & 8 \\
\hline $\begin{array}{l}\text { tetracy- } \\
\text { cline }\end{array}$ & 12 & 25 & 16 & - & - \\
\hline Nystatin & - & - & - & 25 & 23 \\
\hline
\end{tabular}

\section{Observations}

1. The antimicrobial activity of compounds $\mathbf{4 a}$ (p-chloro phenyl), and $\mathbf{4 b}$ (o-chloro phenyl) exhibited more active than standard tetracycline, while the activity of $\mathbf{4 d}$ (o- methyl phenyl) is almost equal to 
tetracycline against Staphylococcus aureus (Spl). The antimicrobial activities of compounds such as, $\mathbf{4 c}$ (p-methyl), and $\mathbf{4 e}$ (p-methoxy) are very much close to standard tetracycline.

2. The antimicrobial activity of compounds $\mathbf{4 b}$ (o- chloro phenyl), $\mathbf{4 d}$ (o-methyl phenyl) and $\mathbf{4 e}$ (p-methoxy phenyl substituents) is by and large similar to the standard tetracycline against Klebsiella pneumonia (Sp2), while 4a (p-chloro phenyl) and $\mathbf{4 c}$ (p-methyl phenyl substituents) are less than standard tetracycline.

3. Compounds $\mathbf{4 b}$ (o-chloro phenyl), 4d (o-methyl phenyl), and $4 \mathbf{e}$ (p-methoxy phenyl substituents) show maximum activity against Proteus mirablis (Sp3) while a considerable activity is shown by the compounds $\mathbf{4 a}$ (p-chloro phenyl) and $\mathbf{4 c}$ (p-methyl phenyl substituents) as compared to standard tetracycline.

4. Maximum activity is shown by the compounds $\mathbf{4 a}$ (p- chloro phenyl), $\mathbf{4 b}$ (o-chloro phenyl) and $\mathbf{4 d}$ (o-methyl phenyl substituents) against Fusarium Chlamydo sporium-fungi (Sp4). However, considerable activity is shown by the compounds $\mathbf{4 c}$ (p-methyl phenyl) and $\mathbf{4 e}$ (p-methoxy phenyl substituents) as compared to standard Nystatin.

5. Compounds $\mathbf{4 a}$ (p-chloro phenyl), $\mathbf{4 b}$ (o-chloro phenyl) and $\mathbf{4 d}$ (o-methyl phenyl substituents) exhibited the maximum activity, while considerable activity is show by the compounds, $\mathbf{4 c}$ (p-methyl phenyl) and 4e (p-methoxy phenyl substituents) against Macrophomina phaseolina (Sp5) as compared to standard Nystatin.

\section{CONCLUSION}

In summary the authors have established a facile synthesis of 2-(4-(benzo[d]thiazol-2-yl) phenylimino) thiazolidin-4-one and 2-(4-(benzo[d]thiazol-2-yl)phenylimino)-5-arylidenethiazolidin-4-ones. 4(benzo[d]thiazol-2-yl)benzenamine (1) reacts with ammonium thiocyanate in presence of Hydrochloric acid to give 1-(4-(benzo[d]thiazol-2-yl)phenyl)thiourea (2) which on reaction with Chloroacetylchloride offer 2-(4-(benzo[d]thiazol-2-yl)phenylimino)thiazolidin-4-one (3). Compound 3 condensed with different aldehydes to produce 2-(4-(benzo[d]thiazol-2-yl) phenylimino)-5-arylidenethiazolidin-4-ones (4a-j). Minimal inhibitory concentration (MIC) measurement and "in vitro" antimicrobial assay (biological activity) of the prepared compounds were also studied against different types of bacteria viz., Staphylococcus aureus (Sp1), Klebsiella pneumoniae(Sp.2), Proteus mirablis (Sp3), and fungi such as, Fusarium Chlamydo sporium(Sp4.), Macrophomina phaseolina (Sp5), using tetracycline and nystatin standards. The studies revealed that the prepared compounds exhibit fairly good antimicrobial activity.

\section{ACKNOWLEDGMENT}

The authors are indebted to Professor T. Navaneeth Rao (Former Vice-Chancellor, O.U), Prof. P. K. Saiprakash (Former Science Faculty Dean, O. U), Head, Department of Chemistry (O.U.), and Chemistry Head, and Principal, P. G. College of Science (O.U), Saifabad for constant encouragement and facilities.

\section{REFERENCES}

1. (a)S. P. Singh, S. S. Parmar, K. Raman and V. I. Stenberg, Chem. Rev., 81, 175(1981); (b) Y. Pandey, P. K. Sharma, N. Kumar, and A. Singh, Int. J. Pharm.Tech. Res., 3, 980(2011).

2. M. D. Ruan, Z. J. Wu, W. Q. Fan and H. Lin, Synth. Commun., 22, 2883(1992).

3. M. Chandrasekharam, O. Mukherjee Singh, H. Ila and H. Junjappa, Synth. Commun., 28, 3073(1998).

4. M. Dischia, G. Prota, R. C. Rotteveel and W. Westerhof, Synth. Commun., 17, 1577(1987).

5. A. Hirashima, H. Tarui and M. Eto, Biosci. Biotech. Biochem., 58, 1206(1994).

6. K. Omar, A. Geronikoki, P. Zoumpoulakis, C. Camoutsis, M. Sokovic, A. Ciric and J. Glamoclija, Bioorg. Med. Chem., 18, 426(2010).

7. K. Taori, V. J. Paul and H. Luesch, J. Am. Chem. Soc., 130, 1806(2008).

8. A. Kumar, C. S. Rajput and S. K. Bhati, Bioorg. Med. Chem., 15, 3089(2007).

9. M. Maymona and M. M. Kandeel, PSSi, 156, 225(2000).

10. (a) P. V. G. Reddy, Y. W. Lin and H. T. Chang, ARKIVOC, 16, 113(2007); (b) W. Liu, S. Wang, Y. Chen, Y. Huang, Z. Li and A. Wang, PSSi, 191, 689(2016). 
11. (a) K. Mistry and K. R. Desai, Indian. J. Chem., 45B, 176(2006); (b) T. Singh, S. Sharma, V. K. Srivastava and K. Ashok Indian, J. Chem.,45B, 1557(2006).

12. S. Singh and P. Singh, Indian J. Het Chem., 15, 263(2006).

13. (a) Y. H. Fan, H. Chen, A. Natarajan, Y. Guo, F. Harbinski, W. I. Christ, H. Aktas and J. A. Halperin, Bioorg. Med. Chem. Lett., 14, 2547(2004); (b) R. Maccari, R. Ottana, C. Curinga, M. G. Vigorita, D. Rakowitz, T. Steindl and T. Langer, Bioorg. Med. Chem., 13, 2809(2005); (c) Y. Luo, L. Ma, H. Zheng, L. Chen, R. Li, C. He, S. Yang, X. Ye, Z. Chen, Z. Li, Y. Gao, J. Han, G. He, L. Yang and Y. Wei, J. Med. Chem., 53, 273(2010).

14. (a) S. J. Hughes, D. S. Millan, I. C. Kilty, R. A. Lewthwaite, J. P. Mathias, M. A. O'Reilly, A. Pannifer, A. Phelan, F. Stuhmeier, D. A. Baldock and D. G. Brown, Bioorg. Med. Chem. Lett., 21, 6586(2011); (b) U. R. Pratap, D. V. Jawale, R. A. Waghmare, D. L. Lingampalle and R. A. Mane, New J. Chem., 35, 49(2011).

15. (a) F. C. Brown, Chem. Rev., 61, 463(1961); (b) S. P. Singh, S. S. Parmar, K. Raman and V. I. Stenberg, Chem. Rev., 81, 175(1981).

16. (a) A. Verma and S. K. Saraf, Eur. J. Med. Chem., 43, 897(2008); (b) T. Tomasic and L. P. Masic, Curr. Med. Chem., 16, 1596(2009).

17. (a) M. Joshi, C. Vargas, P. Boisguerin, A. Diehl, G. Krause, P. Schmieder, K. Moelling, V. Hagen, M. Schade and H. Oschkinat, Angew. Chem. Int. Ed., 45, 3790(2006); (b) T. Sohda, K. Mizuno and Y. Kawamatsu, Chem. Pharm. Bull., 32, 4460(1984).

18. F. Yu, H. Hu, X. Gu and J. Ye, Organic Lett., 14, 2038(2012).

19. G. P. Lu, L.Y. Zeng and C. Cai, Green Chem., 13, 998(2011).

20. S. Paladhi, A. Chauhan, K. Dhara, A. K. Tiwaria and J. Dash, Green Chem., 14, 2990(2012).

21. N. Hamdi, A. S. Al-Ayed, R. B. Said and A. A. Fabienne, Molecules, 17, 9321(2012).

[RJC-1604/2017] 